\title{
COMPARATIVE STUDY OF CIRCADIAN RHYTHM OF PEAK EXPIRATORY FLOW RATE IN SOUTH INDIAN HEALTHY FEMALES AND ASTHMATIC FEMALES
}

\author{
Sindhura Koganti1 ${ }^{1}$ Dhanasekar T2 ${ }^{2}$ Anisha ${ }^{3}$, Abdul Majeed Arshad ${ }^{4}$, Hemanth L ${ }^{5}$, Chandrasekar $C^{6}$ \\ ${ }_{1}^{1}$ Assistant Professor, Department of Chest and TB, Sri Ramachandra Medical College and Research Institute. \\ ${ }^{2}$ Associate Professor, Department of Chest and TB, Sri Ramachandra Medical College and Research Institute. \\ ${ }^{3}$ Respiratory Therapist, Department of Chest and TB, Sri Ramachandra Medical College and Research Institute. \\ ${ }^{4}$ Assistant Professor, Department of Chest and TB, Sri Ramachandra Medical College and Research Institute. \\ ${ }_{5}^{5}$ Assistant Professor, Department of Chest and TB, Sri Ramachandra Medical College and Research Institute. \\ ${ }^{6}$ Professor, Department of Chest and TB, Sri Ramachandra Medical College and Research Institute.
}

\section{ABSTRACT}

\section{AIM AND OBJECTIVES}

Cross-sectional study to compare the peak expiratory flow rate with the help of "Mini-Wright" peak flow meter among females, normal healthy subjects and subjects who are asthmatics of age group 20-40 years.

\section{METHOD}

60 adult females of age group 20-40 years (30-Healthy and 30-Asthmatics) for whom baseline pulmonary function testing was done to differentiate normal and asthmatic. All cases were clinically examined to rule-out any obvious cardiopulmonary diseases. Subjects were provided one mini Wright's peak expiratory flow meter, were individually trained for measuring their own PEFR in $\mathrm{L} / \mathrm{min}$ and were instructed to record the readings with Wright's portable peak flow meter at 5:00 am, 8:00 am, 11:00 am, 14:00 pm, 17:00 pm, 20:00 pm and 23:00 pm on two consecutive days. They were instructed to obtain at least three recordings at a time.

\section{RESULTS}

In healthy subjects it is observed that mean PEFR values at morning 5:00 hours was 276.966, which is the lowest value of day and 440.653 at evening 17:00 hour, which is the highest value of the day for this shows there is a progressive rise of about $59.1 \%$ in mean PEFR value from early morning till evening and at night 11:00 hours we got a mean value of 340.143, a decline of $22.809 \%$ when compared to peak value of the day (17:00 hours). In Asthmatic, early morning mean PEFR value at 5:00 hours was 157.888, which is lowest value of the day and 369.774 at evening at 17:00 hours, which is the highest mean PEFR value of the day. There is a significant rise of about $134.2002 \%$ in the mean PEFR value from early morning till evening and at night 11:00 hours we got a mean value of 197.666 , a decline of $46.5441 \%$ when compared to peak value of the day (17:00 hours).

\section{CONCLUSION}

It is seen that though the circadian rhythm in asthmatics follows a similar pattern, i.e. PEFR dip in morning and PEFR peak in late afternoon, but the swing of PEFR from the mean value is more than in normal subjects. A small portion of people with asthma may benefit from regular peak flow monitoring.

\section{KEYWORDS}

PEFR, Asthmatics, Circadian Rhythm.

HOW TO CITE THIS ARTICLE: Koganti S, Dhanasekar T, Anisha, et al. Comparative study of circadian rhythm of peak expiratory flow rate in south Indian healthy females and asthmatic females. J. Evolution Med. Dent. Sci. 2016;5(15):700-706, DOI: $10.14260 /$ jemds/2016/162

\section{INTRODUCTION}

The phenomenon of nocturnal asthma has always perplexed clinician's and researcher's mind. Peak Expiratory Flow Rate (PEFR) variability has been suggested as a marker for bronchial hyper-reactivity in asthmatic individuals.(1,2) PEFR variation has been widely advocated and used in clinical practice and asthma research. The National Heart Lung and Blood Institute (NHLBI) and others have recommended a diurnal variation of $20 \%$ or more, as a diagnostic benchmark for asthma. $(3,4)$

Financial or Other, Competing Interest: None.

Submission 09-01-2016, Peer Review 04-02-2016,

Acceptance 10-02-2016, Published 22-02-2016.

Corresponding Author:

Dr. Sindhura Koganti,

No. 11/22, Ayyavoo Street, Ayyavoo Naidu Colony,

Aminjikarai, Chennai-29.

E-mail: sindhukoganti@gmail.com

DOI: 10.14260/jemds/2016/162
Further, comparative studies have not sustained the claim to promote PEFR variability for diagnosing asthma because of the lack of standard cut-off value of PEFR variability for labeling a person as asthmatic.(5,6) PEFR shows hour to hour variation that follows a specific pattern in asthmatics as well as in normal individuals as has been identified in earlier studies.(7-9) Most of these studies are done in patient population and adequate data is not available for the circadian rhythm in normal individuals. We therefore evaluated a comparison of the pattern of circadian rhythm of PEFR in healthy and asthmatic South Indian female subjects.

\footnotetext{
AIM

This is a cross-sectional study done at a tertiary care hospital to compare the peak expiratory flow rate with the help of "Mini-Wright" peak flow meter among females, normal healthy subjects and subjects who are asthmatics of age group 20-40 years.
} 


\section{REVIEW OF LITERATURE}

Peak Expiratory Flow Rate (PEFR) recorded on Wrights peak flow meter is commonly used for screening individuals with chronic airway obstruction both in clinical and in field studies. For the assessment and followup of bronchial asthma, PEFR is a reliable parameter. Predicted normal values for PEFR have been shown to have significant geographical and ethnic variation. PEFR shows regular variation that follows a specific pattern in asthmatics and healthy individuals has been identified.

Peak flow meter records peak flow or Peak Expiratory Flow Rate (PEFR), the fastest rate at which air can move through the airways during a forced expiration starting with fully inflated lungs. PEFR correlates well with FEV1, which a spirometer measures. PEFR is typically used for asthma diagnosis by comparing a patient's PEFR with his/her normal personal best PEFR or his/her predicted PEFR value. Peak Expiratory Flow Rate (PEFR) reflects the strength and condition of respiratory muscles and the degree of airflow limitation in large airways.(10)

PEFR is a safe test. There are no risks associated with this test. In rare instances, you may feel a little light-headed after breathing into the machine several times.

Flow rate decreases when there is a bronchospasm. Asthma patients may experience low peak flow rates before they develop breathing symptoms.

In a study done by Dr. Daniel R. Neuspiel and Dr. Cheryl D. Courtlandt, if you have asthma and get a peak flow rate that is less than 80 percent of your personal best you should take your emergency inhaler medication (Quick acting beta2agonist). If your peak flow rate is less than 50 percent of your personal best, should take your quick-acting beta2-agonist medicine and seek immediate medical attention.

PEFR shows hour to hour variation that follows a specific pattern in asthmatics and healthy individuals. It is noted that highest PEFR is seen around the mid-point of the awake period. It has been suggested that the rhythm in plasma cortisol may be the pulmonary clock, since nadir of the cortisol rhythm occurs a few hours before that of PEFR rhythm which would be compatible with the delayed effects of corticosteroids on the airways.(11)

In the study done by M. Goyal et al.(12) 42 healthy, nonsmoking male adults of age group between 18-26 years among university population from north India. The PEFR (L/min.) was measured with Wright's portable peak flow meter at 05:00, 8:00, 11:00, 14:00, 17:00, 20:00 and 23:00 hours. The variability of PEFR revealed a circadian pattern. PEFR levels tend to increase from morning at 5:00 hours till evening at 17:00 hours with peak PEFR in evening at 17:00 hours, after which there was a progressive fall in PEFR levels till morning 5:00 hours. This study provides the preliminary reference data of circadian pattern of PEFR in healthy individuals.

In the study done by M. Amjad Hameed et al.(13) Peak Expiratory Flow Rates (PEFRs) were measured in 424 healthy subjects (213 males and 211 females) from Karachi and Rawalpindi regions of Pakistan. The mean age, height and peak expiratory flow rate for males were $32.82 \pm 10.52 \mathrm{yr}$., $163.5 \pm 5.4 \mathrm{~cm}$ and $478.6 \pm 63.2 \mathrm{l} / \mathrm{min}$ respectively. The corresponding values for females were $35.54 \pm 6.98 \mathrm{yr}$., $157.34 \pm 8.2 \mathrm{~cm}$ and $422.5 \pm 42.6 \mathrm{l} / \mathrm{min}$ respectively. Body height was found to have a positive correlation with PEFR.
The findings of this study provide the baseline data for PEFRs in normal adults.

In the study done by Jenny Jayapal et al.(12) peak expiratory flow rate was recorded in 50 adult healthy female students aged 18-23 years and studying in professional courses. Mini Wright's peak flow meter was used to measure the peak expiratory flow rate. PEFR were recorded at 7-8 am, 10-11 am.

1-2 pm, 4-5 pm and 7-8 pm for two consecutive days. On analysis of PEFR records of individual subjects, it was seen that there was an overall dip in the morning at 7-8 $\mathrm{h}$ PEFR, which increased in the daytime peaking in the afternoon at 1-2 pm and eventually decreased in the night. Subjects did not show the peak PEFR values at the same time point, $10 \%$ of subjects had a rise in PEFR in the early morning, afternoon (1-2 pm) peak was observed in $48 \%$ subjects and evening ( $4-5 \mathrm{pm}$ ) peak was observed in $16 \%$ subjects; $14 \%$ subjects showed a peak in the night time (7-8 pm) PEFR values.

In the Study done by Jamison JP et al.(6) normal $(n=24)$ and asthmatic $(n=123)$ subjects aged $10-70$ years were recruited from the community.

Subjects recorded their peak flow immediately after rising in the morning at 18:00 hours and just before retiring at night for 12 days. The most discriminating index was the highest peak flow variability, which occurred within any 1 day during the 12-day recording period, calculated as the difference between the maximum and minimum peak flows expressed as a percentage of the minimum peak flow on that day (The proposed index).

This index was $<20 \%$ (90th centile) in $96 \%$ of the normal subjects and $>$ or $=20 \%$ in $89 \%$ of the asthmatic subjects. Standard indices of mean peak flow, the forced expiratory volume in 1.0s and its responsiveness to salbutamol had much lower sensitivities than peak flow variability. It is concluded that numerical indices of peak flow variability are highly valid tests for asthma. Using an upper limit of normal of $20 \%$, the proposed index of peak flow variability discriminates better than other indices between asthmatic and normal subjects.

\section{MATERIALS AND METHODS}

This study was conducted in 60 adult females of age group 2040 years (30-Healthy and 30-Asthmatics). Nature of the study was explained to each subject prior to participation in the study. All subjects were living in same environmental conditions and had almost similar daily routine. All subjects underwent baseline pulmonary function testing to differentiate normal and asthmatic subjects. ${ }^{12}$ A detailed history was taken and they were clinically examined to rule out any obvious cardiopulmonary diseases.

\section{Inclusion Criteria}

- All subjects were females.

- Bronchial asthma -Obstruction on PFT.

- Healthy individuals with no respiratory complaints.

\section{Exclusion Criteria}

- Smokers.

- Tuberculosis.

- Pneumonia.

- Recurrent respiratory tract infection.

- Chest or spinal deformity.

- Cardiorespiratory diseases. 


\section{Protocol}

For the convenience of study, subjects were provided one mini Wright's peak expiratory flow meter, were individually trained for measuring their own PEFR in L/min and were instructed to record the readings with Wright's portable peak flow meter at 5:00 am, 8:00 am, 11:00 am, 14:00 pm, 17:00 pm, 20:00 pm and 23:00 pm on two consecutive days. They were instructed to obtain at least three recordings at a time.

The data sheets were filled for history, clinical examination with height and weight, history of medications and PEFR readings. Only the PEFR readings recorded at 23:00 hour on first day and all readings on the second day were taken into consideration to rule out the remote possibility of training effect.(12) The best of three PEFR readings in a given time was taken for the analysis.

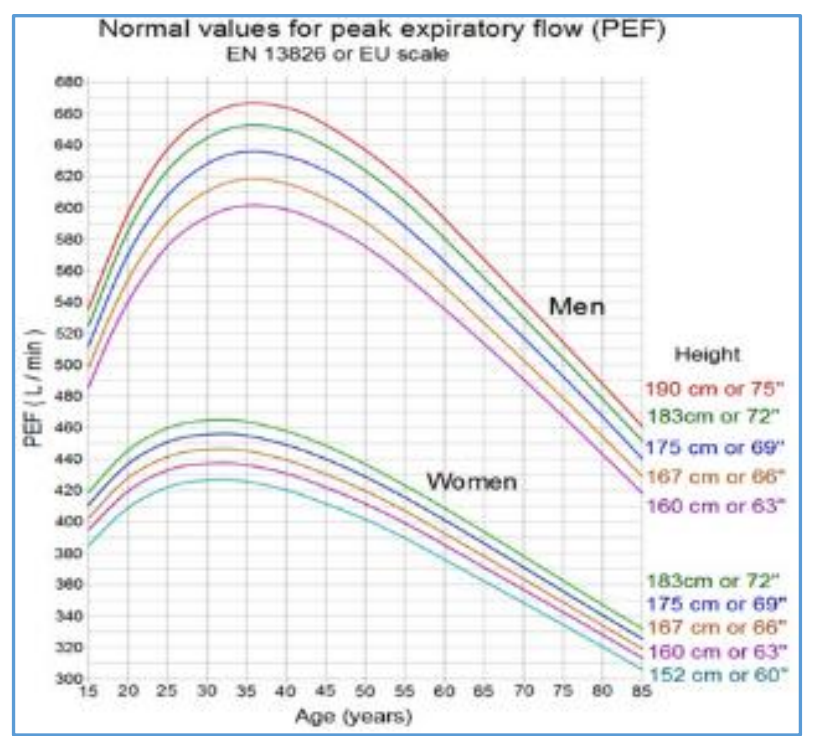

The highest of three readings is used as the recorded value of the Peak Expiratory Flow Rate. It may be plotted out on graph paper charts together with a record of symptoms or using peak flow charting software. This allows patients to selfmonitor and pass information back to their doctor.

\section{Estimated/Expected Peak Expiratory Flow (Peak Flow)}

Formula
Children: PEFR $=(($ Height in $\mathrm{cm}-100) * 5)+100$
Adult Men: $(($ Height $* 5.48)+1.58)-($ Age * 0.041$)) * 60$
Adult Women: $((($ Height $* 3.72)+2.24)-($ Age *0.03) $) * 60$

Peak flow readings are often classified into 3 zones of measurement according to the American Lung Association; green, yellow and red. Doctors and health practitioners can develop an asthma management plan based on the greenyellow-red zones.

\begin{tabular}{|lll|}
\hline $\begin{array}{l}\text { Zone } \\
\text { Green }\end{array}$ & $\begin{array}{l}\text { Reading } \\
80 \text { to } 100 \text { percent of the usual } \\
\text { or normal peak flow readings are clear }\end{array}$ & $\begin{array}{l}\text { Description } \\
\text { A peak flow reading in the green zone indicates } \\
\text { that the asthma is under good control }\end{array}$ \\
$\begin{array}{l}\text { Yellow } \\
\text { Zone }\end{array}$ & $\begin{array}{l}50 \text { to } 79 \text { percent of the usual or } \\
\text { normal peak flow readings }\end{array}$ & $\begin{array}{l}\text { Indicates caution. It may mean respiratory airways } \\
\text { and additional medication may be required }\end{array}$ \\
$\begin{array}{l}\text { Red } \\
\text { Less than } 50 \text { percent of the usual or }\end{array}$ & $\begin{array}{l}\text { Indicates a medical emergency. Severe airway } \\
\text { narrowing may be occurring and immediate } \\
\text { action needs to be taken. This would usually } \\
\text { involve contacting a doctor or hospital. }\end{array}$ \\
\hline
\end{tabular}

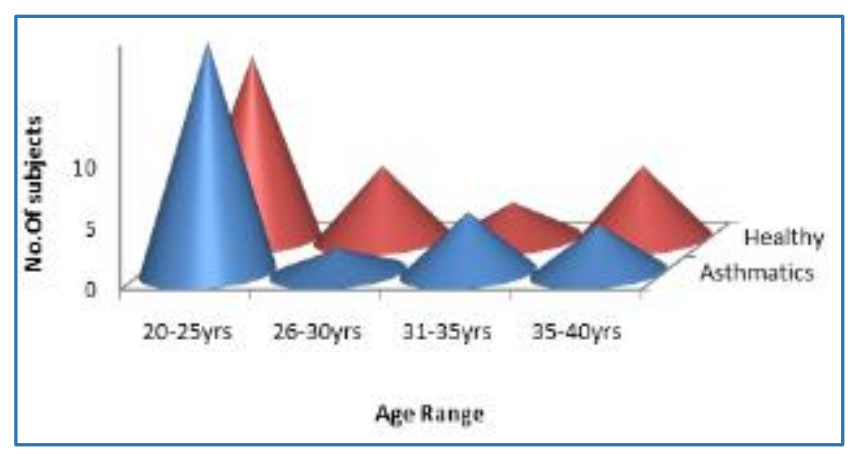

Fig. 1: Range of Age in asthmatics and healthy subjects
In this study we had (Fig. 1)

- 19 healthy and 15 asthmatic subjects in age group 20-25 years.

- 2 healthy and 6 asthmatic subjects in age group 26-30 years.

- $\quad 5$ healthy and 3 asthmatic subjects in age group 31-35 years.

- 4 healthy and 6 asthmatic subjects in age group 36-40 years.

- Shows about $50 \%$ of the subjects are from age group 2025 years. 
On taking mean of age for individuals participated in this study, we got

1. 26 years as mean age for healthy subjects and

2. 28 years as mean age for asthmatics.

\begin{tabular}{|c|c|c|c|c|}
\hline & Mean & N & $\begin{array}{c}\text { Std. } \\
\text { Deviation }\end{array}$ & $\begin{array}{c}\text { Std. Error } \\
\text { Mean }\end{array}$ \\
\hline Pair 5.00am & 276.966 & 30 & 42.2241 & 7.7090 \\
$18.00 \mathrm{am}$ & 377.84 & 30 & 36.341 & 6.635 \\
Pair 8.00am & 377.84 & 30 & 36.341 & 6.635 \\
$211.00 \mathrm{am}$ & 407.864 & 30 & 25.3922 & 4.6360 \\
Pair 11.00am & 407.864 & 30 & 25.3922 & 4.6360 \\
3 2.00pm & 416.317 & 30 & 25.0088 & 4.5660 \\
Pair 2.00pm & 416.317 & 30 & 25.0088 & 4.5660 \\
4 5.00pm & 440.653 & 30 & 23.5158 & 4.2934 \\
Pair 5.00pm & 440.653 & 30 & 23.5158 & 4.2934 \\
5 8.00pm & 366.4980 & 30 & 36.15673 & 6.60129 \\
Pair 8.00pm & 366.4980 & 30 & 36.15673 & 6.60129 \\
6 11.00pm & 340.143 & 30 & 41.0237 & 7.4899 \\
\hline Table 1: PEFR for normal Healthy Subjects (T-Test) \\
\hline
\end{tabular}

PEFR value at morning 5:00 hours was 276.966, 8:00 hours was $377.84,11: 00$ hours was $407.864,14: 00$ hours was $416.317,17: 00$ hours was 440.653, 20:00 hours was 366.498 and 23:00 hours was 340.143 as shown in Table 1.

It is observed that mean PEFR values at morning 5:00 hours was 276.966, which is the lowest value of day and 440.653 at evening 17:00 hour, which is the highest value of the day for healthy subjects. This shows there is a progressive rise of about $59.1 \%$ in mean PEFR value from early morning till evening.
And at night 11:00 hours, we got a mean value of 340.143 , a decline of $22.809 \%$ when compared to peak value of the day (17:00 hours).

\begin{tabular}{|c|c|c|c|c|}
\hline & Mean & N & Std. & $\begin{array}{c}\text { Std. } \\
\text { Error }\end{array}$ \\
\hline Pair 5.00 & 157.888 & 30 & 102.3401 & 18.6847 \\
am & 262.44 & 30 & 62.977 & 11.498 \\
1 8.00am & 262.44 & 30 & 62.977 & 11.498 \\
Pair & 309.830 & 30 & 60.9368 & 11.1255 \\
8.00am & 309.830 & 30 & 60.9368 & 11.1255 \\
211.00am & 327.886 & 30 & 56.4829 & 10.3123 \\
Pair & 327.886 & 30 & 56.4829 & 10.3123 \\
11.00am & 369.774 & 30 & 51.7137 & 9.4416 \\
3 2.00pm & 369.774 & 30 & 51.7137 & 9.4416 \\
Pair & 239.0837 & 30 & 58.66345 & 10.71043 \\
2.00pm & 239.0837 & 30 & 58.66345 & 10.71043 \\
4 5.00pm & 197.666 & 30 & 52.3790 & 9.5631 \\
Pair & \multicolumn{4}{|c|}{} \\
\hline \multicolumn{4}{|l|}{ Table 2: PEFR for asthmatic females T-Test } \\
\hline
\end{tabular}

In asthmatic subjects, mean PEFR value at morning 5:00 hours was 157.888 , 8:00 hours was $262.44,11: 00$ hours was 309.83 , 14:00 hours was $327.886,17: 00$ hours was 369.774 , 20:00 hours was 239.083 and 23:00 hours was 197.666 as shown in Table 2.

This shows early morning mean PEFR value at 5:00 hours was 157.888, which is lowest value of the day and 369 . 774 at evening at 17:00 hours, which is the highest mean PEFR value of the day. There is a significant rise of about $134.2002 \%$ in the mean PEFR value from early morning till evening. And at night 11:00 hours we got a mean value of 197.666, a decline of $46.5441 \%$ when compared to peak value of the day (17:00 hours).

\begin{tabular}{|c|c|c|c|c|c|c|c|}
\hline & $\mathbf{5 : 0 0}$ & $\mathbf{8 : 0 0}$ & $\mathbf{1 1 : 0 0}$ & $\mathbf{2 : 0 0}$ & $\mathbf{5 : 0 0}$ & $\mathbf{8 : 0 0}$ & $\mathbf{1 1 : 0 0}$ \\
\hline TIME & AM & AM & AM & PM & PM & PM & PM \\
\hline ASTHMATIC FEMALES & \multirow{2}{*}{157.88} & 262.44 & 309.83 & 327.88 & 369.77 & 239.08 & 197.66 \\
NORMAL HEALTHY FEMALES & 276.96 & 377.84 & 407.86 & 416.31 & 440.65 & 366.49 & 340.14 \\
\hline
\end{tabular}

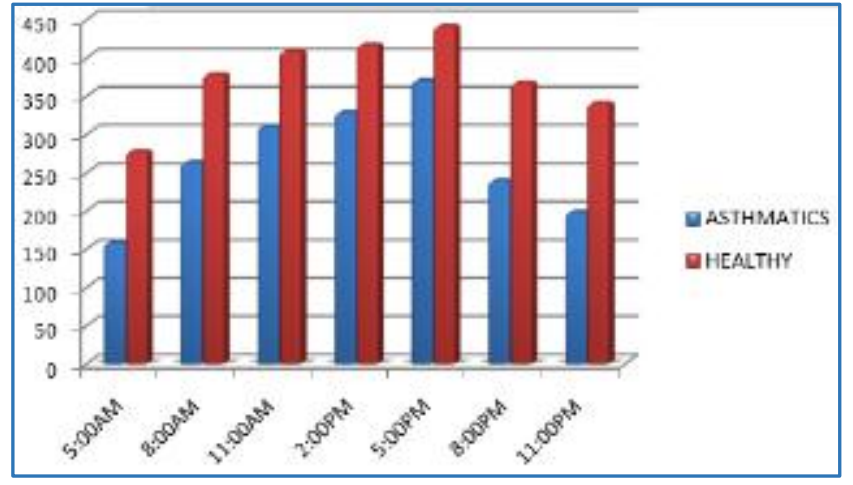

Fig. 2: Mean PEFR value of asthmatics and normal subjects at different time intervals

\begin{tabular}{|c|c|c|c|c|c|c|c|}
\hline & $\mathbf{5 : 0 0}$ & $\mathbf{8 : 0 0}$ & $\mathbf{1 1 : 0 0}$ & $\mathbf{2 : 0 0}$ & $\mathbf{5 : 0 0}$ & $\mathbf{8 : 0 0}$ & $\mathbf{1 1 : 0 0}$ \\
\hline TIME & AM & AM & AM & PM & PM & PM & PM \\
\hline S.D & 102.34 & 62.97 & 60.93 & 56.48 & 51.71 & 58.66 & 52.37 \\
\hline & 42.22 & 36.34 & 25.39 & 25 & 23.51 & 36.15 & 41.02 \\
\hline
\end{tabular}

The mean PEFR values after a dip in morning at 5:00 hours tend to increase throughout the day, peaking in evening at 17:00 hours for both normal subjects as well as asthmatics as shown in Fig. 2. The PEFR values were not recorded at 2:00 $\mathrm{AM}$, but trend suggests that after 17:00 hours there is a regular fall in PEFR levels till 5:00 hours. 


\section{Group Statistics}

\begin{tabular}{|c|c|c|c|c|}
\hline GROUP & N & Mean & Std. Deviation & $\begin{array}{c}\text { Std. Error } \\
\text { Mean }\end{array}$ \\
\hline 5.00 am PEFR FOR ASTHMATIC FEMALES & 30 & 157.888 & 102.3401 & 18.6847 \\
PEFR FOR NORMAL HEALTHY FEMALES & 30 & 276.966 & 42.2241 & 7.7090 \\
\hline 8.00 am PEFR FOR ASTHMATIC FEMALES & 30 & 262.44 & 62.977 & 11.498 \\
PEFR FOR NORMAL HEALTHY FEMALES & 30 & 377.84 & 36.341 & 11.1255 \\
\hline 11.00 am PEFR FOR ASTHMATIC FEMALES & 30 & 309.830 & 60.9368 & 4.6360 \\
PEFR FOR NORMAL HEALTHY FEMALES & 30 & 407.864 & 25.3922 & 10.3123 \\
\hline 2.00 pm PEFR FOR ASTHMATIC FEMALES & 30 & 327.886 & 56.4829 & 4.5660 \\
PEFR FOR NORMAL HEALTHY FEMALES & 30 & 416.317 & 25.0088 & 9.4416 \\
\hline 5.00 pm PEFR FOR ASTHMATIC FEMALES & 30 & 369.774 & 51.7137 & 10.71043 \\
PEFR FOR NORMAL HEALTHY FEMALES & 30 & 440.653 & 23.5158 & 6.60129 \\
\hline 8.00 pm PEFR FOR ASTHMATIC FEMALES & 30 & 239.0837 & 58.66345 & 9.5631 \\
PEFR FOR NORMAL HEALTHY FEMALES & 30 & 366.4980 & 36.15673 & 7.4899 \\
\hline 11.00 pm PEFR FOR ASTHMATIC FEMALES & 30 & 197.666 & 52.3790 & 41.0237 \\
PEFR FOR NORMAL HEALTHY FEMALES & 30 & 340.143 & Table 3: Mean PEFR values of both Healthy and Asthmatic subjects & \\
\hline \multicolumn{6}{c}{}
\end{tabular}

Table 3 shows an overall mean PEFR value of both healthy and asthmatic subjects who participated in the study. Our results suggest that PEFR in these subject exhibits definite circadian rhythm, characterized by nadir in early morning followed by progressive rise in late afternoon and fall night.(12) The highest PEFR is seen at 17:00 hours and lowest between midnight and 5:00 hours in early morning.

While comparing the values of asthmatics and normal subject, variation is seen more in asthmatics. The rise in mean PEFR value from early morning 5:00 hours to evening 17:00 hours in asthmatics is about more than twice when compared to that of healthy subjects and at night 11:00 hours, there is about $23.7351 \%$ more decline in the values of asthmatics, once that of healthy subjects, when compared to the peak value of the day, which might be due to exposure to the dust or other pollutants of the day. Independent Samples Test.

\begin{tabular}{|c|c|c|c|c|c|c|c|c|c|}
\hline & \multicolumn{2}{|c|}{$\begin{array}{c}\text { Levene's Test } f \text { or } \\
\text { Equality of } V \\
\text { ariances }\end{array}$} & \multicolumn{7}{|c|}{ t-test f or Equality of Means } \\
\hline & \multirow[t]{2}{*}{$\mathbf{F}$} & \multirow[t]{2}{*}{ Sig. } & \multirow[t]{2}{*}{$\mathbf{t}$} & \multirow[t]{2}{*}{ df } & \multirow{2}{*}{$\begin{array}{c}\text { Sig. } \\
\text { (2-tailed) }\end{array}$} & \multirow{2}{*}{$\begin{array}{c}\text { Mean } \\
\text { Difference }\end{array}$} & \multirow{2}{*}{$\begin{array}{l}\text { Std. Error } \\
\text { Difference }\end{array}$} & \multicolumn{2}{|c|}{$\begin{array}{c}95 \% \text { Confidence Interval of } \\
\text { the Difference }\end{array}$} \\
\hline & & & & & & & & Lower & Upper \\
\hline $\begin{array}{c}5.00 \text { am Equal variances } \\
\text { assumed } \\
\text { Equal variances not } \\
\text { assumed }\end{array}$ & .742 & .392 & $\begin{array}{l}-5.891 \\
-5.891\end{array}$ & $\begin{array}{c}58 \\
38.595\end{array}$ & $\begin{array}{l}.000 \\
.000\end{array}$ & $\begin{array}{l}-119.0777 \\
-119.0777\end{array}$ & $\begin{array}{l}20.2125 \\
20.2125\end{array}$ & $\begin{array}{l}-159.5374 \\
-159.9750\end{array}$ & $\begin{array}{l}-78.6179 \\
-78.1803\end{array}$ \\
\hline $\begin{array}{c}8.00 \text { am Equal variances } \\
\text { assumed } \\
\text { Equal variances not } \\
\text { assumed }\end{array}$ & 12.560 & .001 & $\begin{array}{l}-8.693 \\
-8.693\end{array}$ & $\begin{array}{c}58 \\
46.386\end{array}$ & $\begin{array}{l}.000 \\
.000\end{array}$ & $\begin{array}{l}-115.400 \\
-115.400\end{array}$ & $\begin{array}{l}13.275 \\
13.275\end{array}$ & $\begin{array}{l}-141.973 \\
-142.116\end{array}$ & $\begin{array}{l}-88.827 \\
-88.685\end{array}$ \\
\hline $\begin{array}{c}11.00 \text { am Equal variances } \\
\text { assumed } \\
\text { Equal variances not } \\
\text { assumed }\end{array}$ & 16.917 & .000 & $\begin{array}{l}-8.134 \\
-8.134\end{array}$ & $\begin{array}{c}58 \\
38.776\end{array}$ & $\begin{array}{l}.000 \\
.000\end{array}$ & $\begin{array}{l}-98.0343 \\
-98.0343\end{array}$ & $\begin{array}{l}12.0527 \\
12.0527\end{array}$ & $\begin{array}{l}-122.1605 \\
-122.4178\end{array}$ & $\begin{array}{l}-73.9081 \\
-73.6509\end{array}$ \\
\hline $\begin{array}{c}2.00 \mathrm{pm} \text { Equal variances } \\
\text { assumed } \\
\text { Equal variances not } \\
\text { assumed }\end{array}$ & 17.021 & .000 & $\begin{array}{l}-7.841 \\
-7.841\end{array}$ & $\begin{array}{c}58 \\
39.950\end{array}$ & $\begin{array}{l}.000 \\
.000\end{array}$ & $\begin{array}{l}-88.4307 \\
-88.4307\end{array}$ & $\begin{array}{l}11.2779 \\
11.2779\end{array}$ & $\begin{array}{l}-111.0059 \\
-111.2251\end{array}$ & $\begin{array}{l}-65.8554 \\
-65.6362\end{array}$ \\
\hline $\begin{array}{c}5.00 \mathrm{pm} \text { Equal variances } \\
\text { assumed } \\
\text { Equal variances not } \\
\text { assumed }\end{array}$ & 13.883 & .000 & $\begin{array}{l}-6.834 \\
-6.834\end{array}$ & $\begin{array}{c}58 \\
40.501\end{array}$ & $\begin{array}{l}.000 \\
.000\end{array}$ & $\begin{array}{l}-70.8787 \\
-70.8787\end{array}$ & $\begin{array}{l}10.3719 \\
10.3719\end{array}$ & $\begin{array}{l}-91.6403 \\
-91.8330\end{array}$ & $\begin{array}{l}-50.1170 \\
-49.9243\end{array}$ \\
\hline $\begin{array}{c}8.00 \mathrm{pm} \text { Equal variances } \\
\text { assumed } \\
\text { Equal variances not } \\
\text { assumed }\end{array}$ & 6.122 & .016 & $\begin{array}{l}-10.127 \\
-10.127\end{array}$ & $\begin{array}{c}58 \\
48.254\end{array}$ & $\begin{array}{l}.000 \\
.000\end{array}$ & $\begin{array}{l}-127.41433 \\
-127.41433\end{array}$ & $\begin{array}{l}12.58135 \\
12.58135\end{array}$ & $\begin{array}{l}-152.599 \\
-152.707\end{array}$ & $\begin{array}{l}-102.230 \\
-102.121\end{array}$ \\
\hline $\begin{array}{c}11.00 \mathrm{pm} \text { Equal variances } \\
\text { assumed } \\
\text { Equal variances not } \\
\text { assumed } \\
\end{array}$ & 1.494 & .227 & $\begin{array}{l}-11.729 \\
-11.729\end{array}$ & $\begin{array}{c}58 \\
54.851\end{array}$ & $\begin{array}{l}.000 \\
.000\end{array}$ & $\begin{array}{l}-142.4773 \\
-142.4773\end{array}$ & $\begin{array}{l}12.1470 \\
12.1470\end{array}$ & $\begin{array}{l}-166.7923 \\
-166.8220\end{array}$ & $\begin{array}{l}-118.1624 \\
-118.1327\end{array}$ \\
\hline & & & & Sian & $f$ & dy readin & & & \\
\hline
\end{tabular}


In this study, all the readings of PEFR which were taken are significant.

\section{DISCUSSION}

This study provided the preliminary reference data of circadian rhythm of PEFR in healthy individuals as well as a comparison with the circadian rhythm of asthmatics. Our results suggest that PEFR values exhibits definite circadian rhythm characterized by a morning dip followed by progressive rise peaking in the evening and small fall at bed time. This was the commonest pattern observed in most of the subjects. In earlier reports lesser percentage of subjects followed this pattern, although having overall circadian pattern similar to the present study. Higher prevalence of identifiable rhythm in greater percentage of subjects in present study may be because of homogeneity of our subject group. Moreover, all the 60 subjects (Both normal and asthmatic) were living in same environmental conditions and had almost similar daily routine.

The circadian rhythm in asthmatics although follows almost similar pattern, i.e. with PEFR dip in morning and PEFR peak in evening, but the swing of PEFR from the mean value is more than in normal subjects. $(14,15)$

The exaggeration of normal pattern of PEFR variability may be considered as a useful marker for diagnosing asthma, the normal pattern however is not found to be universally applicable, has serious limitations. This conclusion in no way should undermine the utility and credibility of PEFR variation in monitoring and routine management of asthmatic patients. The knowledge of normal circadian pattern of PEFR in healthy subjects and its variation might help in better understanding of pathophysiology of nocturnal symptoms present in some asthmatic patients. Therefore, the use of PEFR variability for population screening and clinical diagnosis of asthma.

\section{CONCLUSION}

Peak flow readings are higher when patients are well and lower when the airways are constricted. From changes in recorded values, patients and doctors may determine lung functionality, severity of asthma symptoms and treatment.

First measure of precaution would be to check patient for signs and symptoms of asthmatic hypervolemia. This would indicate whether or not to even continue with the Peak Flow Meter procedure. Measurement of PEFR requires training to correctly use a meter and the normal expected value depends on a patient's sex, age and height. It is classically reduced in obstructive lung disorders such as asthma.

A small portion of people with asthma may benefit from regular peak flow monitoring. When monitoring is recommended, it is usually done in addition to reviewing asthma symptoms and frequency of reliever medication use. Flow rate lessens when the airways are blocked. Asthma patients may experience low peak flow rates before they develop breathing symptoms.

It is seen that though the circadian rhythm in asthmatics follows a similar pattern, i.e. PEFR dip in morning and PEFR peak in late afternoon, but the swing of PEFR from the mean value is more than in normal subjects.

To conclude this study provides important information, i.e. that there is a significant variation in peak expiratory flow rate between morning and evening in population. This has an important bearing in understanding the behaviour of airways in producing changes in PEFR and may be considered as a useful marker in the diagnosis of asthma.(16)

\section{REFERENCES}

1. Higgins BG, Britton JR, Chinn S, et al. Comparison of bronchial reactivity and peak expiratory flow variability measurements for epidemiological studies. Am Rev Resp Dis 1992;145:588-593.

2. Neukirch F, Liard R, Segala C, et al. Peak expiratory flow variability and bronchial responsiveness to methacholine. An epidemiologic study in 117 workers. Am Rev Resp Dis 1992;146:71-75.

3. National Asthma Education and Prevention Program. Expert panel report 2: Guidelines for 68 Goyal, et al. Indian J Physiol Pharmacol 2008;52 (1) the diagnosis and management of asthma. Bethesda, MD.: National Institutes of Health, 1997. (NIH Publication no. 97-4051).

4. Kunzli N, Stutz EZ, Perruchoud AP, et al. Peak flow variability in the SAPALDIA study and its validity in screening for asthma-related conditions. The SAPALDIA Team. Am J Resp Crit Care Med 1999;160:427-434.

5. Goldstein MF, Veza BA, Dunsky EH, et al. Comparisons of peak diurnal expiratory flow variation, postbronchodilator FEV1 responses and methacholine inhalation challenges in the evaluation of suspected asthma. Chest 2001;119(4):1001-1010.

6. Jamison JP, McKinley RK, et al. Validity of peak expiratory flow rate variability for the diagnosis of asthma. Clin Sci 1993;85(3):367-371.

7. Casale R, Pasqualetti $\mathrm{P}$, et al. Cosinor analysis of circadian peak expiratory flow variability in normal subjects, passive smokers, heavy smokers, patients with chronic obstructive pulmonary disease and patients with interstitial lung disease. Respiration 1997;64(4):251-256.

8. Thiadens HA, De Bock GH, Dekker FW, et al. Value of measuring diurnal peak flow variability in the recognition of asthma: a study in general practice. Eur Resp J 1998;12(4):842-847.

9. Aggarwal AN, Gupta D, Kumar V, et al. Assessment of diurnal variability of peak expiratory flow in stable asthmatics. J Asthma 2002;39(6):487-491.

10. Jayapal J, et al. Department of Physiology, Manikkudi Venkataraman Jayaraman Medical College and Research Hospital, Hoskote, Bangalore, Karnataka, India. A study of diurnal variation in peak expiratory flow rates in healthy adult female subjects in South India. CHRISMED J Health Res 2014;1:184-6.

11. Soutar CA, Costello J, Ijaduola 0, et al. Nocturnal and morning asthma: relationship to plasma corticosteroids and response to cortisol infusion. Thorax 1975;30:436-40.

12. A study was done by Goyal M, Goel A, Kumar P, et al. from Department of Physiology, Department of Pulmonary Medicine - King George's Medical University, Lucknow and Department of Physiology- Ganesh Shankar Vidyarthi Medical College, Kanpur, 2008;52(1):64-68.

13. A study was done by Amjad Hameed M, Saadat Ali Khan, et al. (Department of Physiology, Army Medical College, Rawalpindi), Pages 363-364. 
14. Van Keimpema AR, Ariaansz M, Tamminga JJ, et al. Nocturnal waking and morning dip of peak expiratory flow in clinically stable asthma patients during treatment. Occurrence and patient characteristics. Respiration 1997;64(1):29-34.

15. Enright PL, Burchette RJ, Peters JA, et al. Peak flow lability: association with asthma and spirometry in an older cohort. Chest 1997;112(4):895-901.
16. Richa G Thaman, et al. -Assistant professor, Department of Physiology, Sri Guru Ram Das Institute of Medical Sciences and Research, Amritsar, Punjab, Kawalinder K GirglaAssociate Professor, Department of Physiology, Sri Guru Ram Das Institute of Medical Sciences and Research, Amritsar, Geeti P Arora-Department of Medicine, Deep Multispeciality Hospital, Ludhiana, Punjab. Peak expiratory flow rate (PEFR), circadian variation, bronchial hyper-reactivity, Indian geriatric population. JIACM 2010;11(3):195-8. 